Int.J. Hum. Soc. Dev. Res.

ISSN(P):2521-1439; ISSN(E):2523-4331

Volume 5, Number 1, 2021. 25-38

DOI: $10.30546 / 2523-4331.2021 .5 .1 .25$

\title{
CROSS CULTURALISM IN SELECTED LITERARY TEXTS OF THE COASTAL NATIONS OF WEST AFRICA
}

\author{
Rabiu Olayinka IYANDA \\ College of Humanities and Culture, Ikire Campus \\ Osun State University, Osogbo, Nigeria
}

(C) The Author(s) 2021

\section{ABSTRACT}

Cross culturalism remains a current research topic in this contemporary era. It has become the focal point of linguists, psychologists, anthropologists and literary writers among others. They all continue to make discoveries on the effects and factors militating against language, literature and culture and how they can contribute to mutual existence of people from different backgrounds and climes. This paper is an attempt to complement the existing findings and to specifically $x$-ray the challenges stretch by cross culturalism to literary researchers and its prospects in the West African coastal nations. these nations are neighbours naturally and partially of the same cultures, but colonialism changed their perceptions and they hardly share anything in common. Among several factors discovered as impediment to researches in these nations are multilingual and multicultural issues, varied economic fortunes and the difference in the socio-infrastructural developments. The paper proffers suggestions on how these challenges can be surmounted in order for them to achieve their desired goals. The paper concludes that multilingualism is one of several agents that can facilitate smooth research, as ability to use any language effectively could aid the understanding of the culture of the user of the language. This will equally guarantee mutual and coherent working relations at all times.

(C) 2021.All Rights Reserved.

ARTICLE HISTORY

Received: 03/10/2020

Accepted:10/02/2021

Published online:30/04/2021

\section{KEYWORDS}

Culture, language, literature, research, nations, cross culturalism 


\section{Introduction}

Language, culture and literature remain salient factors in literary studies and writings on human affairs. They determine to a large extent the level of interaction and co-existence of man irrespective of their social, political or economic affiliations. This paper looks into some literatures of Nigeria, with Tunde Ajiboye's Le Témoins, The Republic of Benin, with Jean Pliya's La Secrétaire Particulière; Ghana, with Ayi Kwei Armah's, The Beautyful ones are not yet born and Senegal, with Sembène Ousmane's $X a l a$ in a bid to find out the similarities and differences that are being encountered and exposed for a mutual African society irrespective of different geographical identities.

\section{The concept of culture in African literature}

Culture is a dynamic phenomenon encompassing the totality of attitudes, behaviours, beliefs and world-views. It is an integral part of every human society and all social groups are categorized by it. In other words, it is that complex pattern of behavior and material achievement which are produced, learned and shared by members of a community. Ameh (2002: 165). African writers, irrespective of the linguistic background, or the language of expression, safeguard their cultures and transmit such from one generation to another. They teach the younger ones the ethos and etiquettes of the community. Achebe (1988:44) refers to this as education and reeducation process which involves the use of accomplishments. This was well established in his novel, Arrow of God.

\section{Relationship between language, culture and literature}

Across societies, language, culture and literature continue to play domineering roles in the steering and continuity of affairs. Comments, remarks and discussions on these elements are not limited to literary writers. Others such as anthropologists, psychologists, historians and linguists also delve their research in this field of human 
paraphernalia of existence. Before the development of the printing technology, literatures were orally rendered across societies.

The early or late transmitting of oral literature to the writing form is as a result of their technological discovery, both time and level. While some nations achieved their level of technological development very early, some are yet to attain the required level. This oral rendition of literature in which local flavor and aesthetic are fully embedded exists in many African communities till date. Oral literature conveys morals and serves as means of entertainment for community members after the day's work. Through this they preserve and impart the cultural beliefs of the society to the new generations. They also retain the cultural norms as many of these norms were not written. Happenings determine topic of discourse for narrators and writers. Events play a factor in the oral presentation. Writer like the oral narrators also write to pass across certain information as regards happenings in their milieu. Olatunji (1987:42) opines that oral African literature constitutes the store house of priceless instruments of thought which the Africans have laboriously forged through the centuries. Oral literature has great influence on the written African literature both in the African languages and the foreign languages across African nations. Many written literatures by the Africans show significant inspiration of their oral literature. That account for why we have proverbs, fables, myths, songs and several forms of oral literatures incorporated in the written literatures, presented either in the local languages or foreign ones. These elements add to the aesthetic of African literature (both the written and the oral literatures) and distinguish them from other literatures.

\section{The concept of African literature and its different periods}

African literature could be summarily divided into four periods, the pioneering period (1910-1930), the negritude era (1930-1950), the decolonization period (19511960) and the postcolonial literature from 1960 till date. The postcolonial era tends to be much inclusive as writers continue to unfold contemporary issues.

Written African literature could be traced to the era of Negritude movement which started through the efforts of the black African students in diaspora. The effort of these black African students' movement (Harlem Renaissance, and later Negro Renaissance) 
was primarily geared toward reassertion and reevaluation of the beauty and validity of African life patterns.

Their literary works aimed to reposition the literature and culture of Africa as a continent of wise and cultured people. Among the writers of the movement, were WEB Du Bois, Marcus Garvey, Langston Huges, Countee Cullen, L.S. Senghor, Aimé Césaire, Léon Damas, and several others. Since this period, African writers have been charged with happenings and solutions to the undesirable situations through literary and artistic media. They have assumed the role of spokespersons, educators and liberators of black people. They preach 'art for life sake' contrary to the French Parnasse of "l'art pour l'art" of the $19^{\text {th }}$ Century.

Every literary work plays a salient social function. Irrespective of the colonial masters, either the British or the French nationals, themes of African literature across epoch remain unique, the mode of expression, language, is the major different.

\section{Cross culturalism}

Andrew Heywood (2003), Dalrymple Theodore (2004), and Brown Keith (2006) viewed cross culturalism and consent on it as a descriptive term which refers to cultural diversity arising from the existence within a society of two or more groups, whose beliefs and practices generate a distinctive sense of collective identity. Cross culturalism is invariably reserved for communal diversity that arises from racial, ethnic or language differences. As a normative term, cross culturalism implies a positive endorsement of communal diversity, based upon the right of different cultural groups to recognition and respect. In this sense, it acknowledges the importance of beliefs, values and ways of life in establishing a sense of self-worth for individuals and groups alike. It focuses on linguistic and cultural contact.

Adeyemi (2005) agrees with Kelly (2004) on his definition on the concept of cross culturalism: 
The diversity on ethnic and cultural around the country is worthy of enormous praise. It has enabled people of different backgrounds to bridge cultural gaps and live harmoniously through the realization that they are not so different from one another-that humans are human beings, regardless of ethnic root. (4)

Cross culturalism, as the name implies, is much concerned about cultures which encompass language and traditions. It hardly delves into political or economic situation of any area of human endeavours. Dalrymple (2004) opines that all cultures are equal and no fundamental conflict should arise between customs, beliefs, and philosophical outlooks of two different cultures. Fraternization of cultures brings about globalization, which is defined variously by different scholars according to their point of view and areas of specialization. Onyemelukwe (2004), says that globalization is a multidimensional term that seems better explained than defined. She then concludes by saying that

...globalization, implies liberalization (the process of creating an open borderless global economy through revoking government-imposed restrictions on movements of capital, goods and services between countries), universalisation (the process of sharing objects and experiences around the world). Internationalization (the process of fostering growth in global exchange and interdependence of the various member states) and villagisation (the process of turning the whole world into a small village devoid of territorial places, territorial distances and territorial boundaries (222).

She further supplements that with globalization, culture, literature and language are bound to undergo some changes. Textual multilingualism, interlanguage, multilingualism and metatextuality are indicative of the influences of globalization on African literature. This, then, results in fusion of two or more different cultural or religious elements, cultural hybrid.

From these definitions, it is appropriate to conclude that globalization is the growing (worldwide) interdependence of people and countries, it is the process that leads 
towards global interdependence and the increasing rapidity of exchange across vast distances. People of different nationalities then come together to enhance more cultural interactions. This cultural interaction results in cultural conflicts and brings about one culture influencing another which has negative effects on some others. In some cases, some cultures have come across several others. This brings about cross culturalism.

Cross culturalism can be taken to mean the social fact that society more than previously is made up of different cultures. Cultures come in contact with others and results in a new one, in some cases but not always, it only results in cultural modification in many, adulterated culture. In the African literatures, cultures continue to traverse one another in the oral and written literatures. This influence to a large extent the ways these people relate. Could this be linked to globalization? Globalization could be also termed as global trans-culturalism. In all, literature, oral or written, like all other human activities reflects current social, political and economic conditions or classes. It also requires the linguistic intelligibility and competency both for the audience and the storyteller or the writer in the case of written literature.

\section{African literature and cross culturalism}

African literature either written or oral is known for preaching some of the following;

- Respect for parents, elders and those in power of authority

- Importance of hard work and decisive commitment

- Respect for constituted authority and societal norms

- Respect for morality as a guide to behavior in public and private places

- Essential to do good always and shun vices.

Onyemelukwe (2004:148) opines that any literary piece, irrespective of the medium of expression, either in the African languages, French or English language, need to express the people's culture, traditions and sensibilities. The purposeful selection of Anglophone and francophone literary texts for this study is partially to balance the research because of the numerical strength of nations using the French and English 
languages as medium of expression in the coastal nations of the continent of Africa and to buttress the uniformity in African literature.

\section{Anglophone African Writers}

Anglophone African writers could be described as those writers who hail from exBritish colonies like Nigeria, Ghana and they use the English language to present their literary understandings. Onyemelukwe (2004:147) opines that Anglophone African writers are those African writers from British colonized nations and who use English language to produce their literary pieces of creative writings about Anglophone Africans' life and experiences, primarily for Anglophone, and by extension for others in the world. Summarily, Anglophone African writers are Africans from any Ex-British colonized nations and who use English language to write their literary texts. Examples include, Nigerian; Chinua Achebe, Christopher Okigbo, Wole Omotoso, Ghanaian; Ayi Kwei Armah.

\section{Francophone African Writers}

Like the Anglophone writers, the francophone African writers are those from ExFrench colonies who use French as their mode of expressing their literary pieces. They use the French language to present their culture, beliefs and philosophy to people of his cultural background and to others who are from different cultural background but comprehend the French language in faraway places. Examples include, Cameroonians; Mongo Béti, Ferdinand Oyono, Calixthe Beyala, Senegalese, Sembene Ousmane, L.S. Senghor, Ivorian, Fatou Keïta, Régina Yaou.

\section{African literature and theme}


It is remarkable to note that African literary theme remains the same, irrespective of the colonial masters. The literature presents the same topic and same issues. Conditions of living and subsistence are of concern to the literary writers of the continent across periods. Among the common themes in the contemporary African writings include, exploitation of the poor by the nouveaux bourgeois, deception, poor remuneration of workers, drugs abuse, moral decadence, rigging of election, and fight against the neocolonialists. The local problems lead to another theme, migration.

This comes into existence as a result of misgovern and corruption. Many African countries remain undeveloped because of misrule and greed of their leaders. The writing after the independence in almost all African nations has been on neo-colonialism and contemporary issues. Literary writers expose, condemn and correct these bad leadership attitudes through their writings. The post-colonial era in African States is a period of disappointment on hopes and aspirations of the majority. Positive minds towards a better egalitarian African society was dashed, the high hopes and expectations are confronted with neo-colonialism, social injustice, misplacement of priorities and misery. The blacks impose another pain on their fellow blacks. The view privileged ones constitute themselves into another cabal to exploit the majority. Their exploitation is not less than the colonial masters of the era of colonization. They do all sorts of injustices and enrich themselves from the nation's wealth. Xala, Sembene Ousmane exposes the manipulating strategy in the post African nations, Senegalese society. The privileged Africans turn their black fellows to object to be exploited to enrich themselves. Le Mandat criticizes the administrative system of independent Senegalese society.

Discrimination, partiality, embodiment of power abuse, seduction of the less privileged, inducement and corruption are some of the evil games paraded in postindependence Africa nations as demonstrated in the African writings. This will be elaborated in the later parts of this paper Jean Pliya's La Secrétaire Particulière, Tunde Ajiboye Le Témoin, Ayi Kwei Armah The beautiful ones are not yet born. Sembene Ousmane, Xala. All these writers bring into focus, the resultant effects of such practices on the poor innocent citizens which include unemployment, poverty and frustrations and at the moment violence which is borne out against continuous oppression by the privileged blacks in some parts of the continent. 
The play, La Secrétaire Particulière was written by Jean Pliya, a native of Djougou in the Republic of Bénin. The playsets expose in a very objective way the description of African societies characterized by many follies and vices which prevent them from developing, despite their independence from their colonial masters. This literary writing reflects the realities of the contemporary period, happenings after the independence in Africa in general but that of the Republic of Benin in particular. The play is a mirror of post-independence African societies in general.

...notre pays porte en lui, à son insu, le ver qui le ronge. S'il faut accuser les colonialistes et les impérialistes, il est aussi urgent d'assainir la maison. (68)

This shows how corruptible African society looks like after independence.

The play is adaptable to several other independent African nations; the theme is seen in the day to day administration of these nations. The excesses in the bureaucratic setting of post African nations. The ways used by the privileged ones to cheat the weak ones or their subordinates by those in power of authority. The belief in the juju, super natural intervention brings about the total exposure of the Director.

...le jour de l'examen, j'ai porté un talisman. En outre, je compte sur mon oncle, conseiller au ministère de la santé. Je l'ai vu et je le reverrai encore ce soir. "Quand on a un parent sur le pommier, on est sûr de ne pas manger des pommes vertes »(58)

The juju was not properly used and result was not seen. Despite the sacrifices made by Nathalie, the junior secretary, in the play, she suffered for nothing. It is also glaring that many things are influenced and merit is not considered in many occasions. This influential factor affects quality, as 'whom you know and not what you know' is the popular saying of several applicants in these nations.

The Director, Mr. Chadas, rejected the pregnancy of this confidential secretary. He claims of having enough children and wives. 
...j'ai deja une quizaine d'enfants. Avec trois femmes à la fois c'est vite arrivé. (76)

The Beautiful Ones Are Not Yet Born is a reflection of a lifestyle situation that takes place in Africa. The author, Ayi Kwei Armah, expresses the disillusion and distrust bring about in Ghana after independence. It describes the vague ennui of Africans after the independence.

The novel provides a description of the existential things of the book's hero who struggles to remain clean when everyone else around him has succumbed to corruption. A nameless rail worker who is pressured by his family and fellow workers to accept bribes. The theme spins around corruption, military dictatorship country's maladjustment after independence. The book exposes the clash between the lower-class people and people at the helms of affairs in the government circles. Life remains unbearable for many Ghanaians in particular according to the novel, and all Africans nations in general.

Le Témoin is another story written by Tunde Ajiboye a Nigerian. He uses the French language to present his ideas and to criticize the unrestrained behavior of a public officer, police officer, in Nigeria situation which could be applicable to every nations of Africa after independence. The police officer intends to marry the second wife. His salary could not cater for this additional burden. He results to taken 'taxes' from road users, transporters, for his personal upkeep.

... il devenait de plus en plus insatiable en matière d'argent. Il n'y avait pas un jour sous le soleil où il n'arrachait quelque chose aux chauffeurs, innocents ou coupables. Ceux qui n'avaient pas d'argent à offrir apportaient du gibier, ...le Carporal était leur oracle ; il fallait éviter toujours sa colère. (46)

This he continues until one Sunday afternoon when he meets a driver who pleaded not having anything on him that the passengers are on family engagement. This police officer refused to the excuse of the driver. The driver has to disengage all the passengers and go back home to find money for Carporal Koka. On his return, he brought money and gris-gris. He gave the money to Carporal and move forward before reciting the necessary 
incantation on the gourde piquottée de cauris. He finalized life of this Carporal. On reciting these incantations, the Carporal lost his senses and could not control himself.

He becomes an insane an insane. He starts speaking incomprehensible languages. In that place of setting everybody calls him "et tes papiers?" This is the usual utterance by the police officers on the roads. The African super natural power remains, this is what the driver uses for this police officer to show his annoyance and to revolt against such extortion.

Xala is a novel written by Sembene Ousmane, a Senegalese and prolific writer of the post-independence African. Elhadji Kadir Beye exploit others to live a meaningful life. He enjoys the dividends meant for the entire citizenry of his nation. Elhadji Kadir Beye, represents several other African elites or those in the corridor of power. They were elected to see to the welfare of the masses but they turn out to be exploiters. He was elected the representative of the cooperative society, to sell return the capital and make judicious use of the profit for the wellbeing of every individual in the society. Instead of doing this, Elhadji Kadir Beye, builds houses, buys vehicles for himself and his wives and continues to accumulate wives. On the occasion of marrying the third wife, the peasants in the country wage war against him and turn him to a ridicule objet of the society. He becomes impotent and the way out is for all the mendicants in the society to spit on him. He agrees to this but, all to no avail as the xala was not cured. The story shows revolt against oppressor by the masses.

\section{Cross culturalism in the novels}

These novels written in the French and English languages from different nations and by different authors express the same ideas. The solution proffered to their problem of stress looks alike. This shows that our tradition is created upon stories and myths. This could be the foundation for all cultures. Stories are created across nations or societies to make sense of such. Polygamy is common in the stories. It is a common phenomenon in the continent. This could be an acceptance practice of Africans.

The idea of corruption is also parallel in these countries. The post-independence situation seems to remain. The privileged ones continue to exploit the masses, going by these novels and the ways the oppressed used to fight for themselves one will not hesitate 
to recommend such a step for the present political misdemeanor across nations of Africa. The story of Carporal Joé Damkpa Koka, in Le Témoin by Tunde Ajiboye, could be a lesson to those on the roads, those at the border posts of these coastal nations. Corruption is so common in these stories. It X-rays the African societies after the independence, irrespective of the colonial masters, the neo-colonialists remain to milk their fellow Africans.

The ways and manners of discharging duties is nothing to write home about. They could learn some lessons from the story if only they could speak the language used by the writer. Apart from Nigeria, who is more a less a bilingual nation, many other nations of this coastal areas could not speak beyond the language of their colonial masters this is not encouraging as they could not assess several other useful information from their neighbouring nations. It will be an added advantage to be bilingual. This will serve as an assisting factor in carrying out research and other cross nation's endeavours.

\section{Summary and conclusion}

The paper has looked into the post-independence situation of some African countries through some novels from selected African nations. Stories in these novels expose the real colour and situation of things after the 'so called independence'. The only way to intensify the agitation for egalitarian African society is to make those Anglophone nations and francophone nations be bilingual. The ways of doing thing will be made public. This could bring more mutual existence between literary writers. We want to conclude with this quote of Chinua Achebe (1987), he comments on African oral tradition thus:

It is only the story that can continue beyond the war and the warrior. It is the story that outlives the sound of wardrums and the exploits of brave fighters. It is the story... that saves our progeny from blundering like blind beggars into the spikes of the cactus fence. The story is our escort; without it, we are blind. Does the blind man own his escort? No, neither do we own the story; rather it is the story that owns us and directs us (124). 
This shows that irrespective of the language use for communication, the story stands to pass across certain information which will definitely make literature an 'art for life sake'. Although there are several challenges to the increasing diverse world at large, the benefits are greater. Communicating and establishing mutual relationship across nations, most especially the West African states, can lead to a whole host of benefits including increased international, national and local commerce, reduced conflict, healthier communities and increased tolerance which will enhance personal growth of the citizenry.

\section{Disclosure statement}

No potential conflict of interest was reported by the author. 


\section{References and notes:}

Adebayo, A. 2010. The nature and functions of literature: The comparatist's perspective. An inaugural lecture. Ibadan: University of Ibadan press.

Adeyemi Lere. 2005. "The Ideology of Multiculturalism in the works of selected American Minority Group's Novelists: Lessons for Nigerian. Literatures" in IHAFA: A Journal of African Studies, Vol. 5, no. 2. Lagos. University of Lagos.

Ajiboye Tunde, 1997. Le Témoin. Ibadan. Bounty Press Limited.

Ali, A. Mazrui. 1988. "Globalization, Islam and the West: Between Homogenization and Hegemonization" in The American Journal of Islamic Social Sciences. Globalization Vol.15. No. 3. The International Institute of Islamic Thought. (IIIT) Washington D.C.

Ayi Kwei Armah. 1965. The beautiful ones are not yet born. England. Heinemann.

Babawale, Tunde. 2012. Culture, development and empowerment in Africa. Osogbo. Osun State University.

Olatunji, O.O. 1987. Beyond the spoken word: An African language literature experience. Ibadan. University of Ibadan.

Chinua Achebe, 1987. Anthills of the Savannah. Edinburg. Heinemann.

Clayton Edward, 2008. Aesop, Aristotle, and animals: the role of fables in human life in Humanitas. Vol. xxi, nos. 1 and 2, pp $179-200$

Kehinde Ayo \& Mbipom 2011. Discovery, Assertion and Self-Realisation in Recent Nigerian Migrant Feminist Fiction: The Example of Sefi Atta's Everything Good Will Come. In African Nebula. Issue 3 June, pp 62-77.

Onyemelokwe, Ifeoma. 2004. Colonial feminist and postcolonial discourses: decolonisation and globalisation of African literature. Zaria. Labelle Educational Publishers.

Ramonu Sanusi. 2015. Portrayals and gender palaver in francophone African writings. Ibadan. Graduke publishers. 